\title{
Mitochondrial genetic structure of two populations of Uca urugayensis fails to reveal an impact of the Rio de la Plata on gene flow
}

\author{
Claudia Laurenzano, Nahuel E. Farías and Christoph D. Schubart
}

(CL, CDS) Biologie 1, Universität Regensburg. 93040 Regensburg, Germany. E-mails: (CL) claudialaurenzano@gmail.com; (CDS) christoph.schubart@biologie.uni-regensburg.de

(NEF) Laboratorio de Invertebrados, Departamento de Biología, Facultad de Ciencias Exactas y Naturales, Universidad Nacional de Mar Del Plata. CC 1245, CP 7600 Mar del Plata, Argentina

\section{Abstract}

The Rio de la Plata. located between Uruguay and Argentina, generates a tremendous freshwater influx from the estuary into the coastal sea. It is thus suggested to constitute a biogeographic barrier for many taxa exhibiting a marine planktonic larval dispersal. However, evidence for corresponding intraspecific dispersal constraint has yet to be provided. We compared mitochondrial haplotypes of ten individuals for each of two populations of $U c a$ (Leptuca) uruguayensis north and south of the estuary to examine the potential effect of the Rio de la Plata on the species' distribution. The populations are separated by nearly 2,000 km and were collected in São Paulo State (Brazil) and Mar Chiquita (Argentina). We found no significant indication for restricted gene flow between them, based on 823 basepairs of the mitochondrial cytochrome c oxidase subunit I gene. The structure of the corresponding haplotype network and the estimated nucleotide diversities, however, suggest that the Argentinean population is genetically more diverse than the one from Brazil. In order to establish possible significant differences in haplotype distribution, further research including more populations and larger sample sizes will be necessary.

Key words: COI, Genetic homogeneity, mtDNA sequence, Rio de la Plata.

\section{Introduction}

In many marine invertebrates, a planktonic larval development provides the most common reproductive strategy (Epifanio et al., 1988) which results in a high dispersal potential (Palumbi, 1996) and thus may reduce genetic structuring of even remote populations (Palumbi, 1994; Avise, 2004). Nevertheless, reduced dispersal among populations may follow from physical or biological barriers that individuals cannot overcome. Environmental barriers can be formed by e.g. water temperatures or salinities deleterious to larval survival or development (Hedgecock, 1986). Alterations in salinity degrees fatal to invertebrate larvae can result from huge river outflows. Rivers such as the Amazon (e.g. Gilbert, 1972; Briggs, 1974, 1995; Greenfield, 1988, 1989) or the Orinoco (e.g. Gilbert, 1972; Lessios et al., 2003) have already been postulated to form major biogeographical 
barriers to marine invertebrate dispersal. Alike these rivers in northern South America, the Rio de la Plata Estuary in austral South-America $\left(34^{\circ} \mathrm{S}-36^{\circ} 20^{\prime} \mathrm{S}\right.$ and $55^{\circ}-58^{\circ} 30^{\prime} \mathrm{W}$; see Fig. 1 ) is hypothesized to constitute a significant biogeographic boundary to coastal ecosystems (e.g. Bisbal, 1995).

The Rio de la Plata is a relatively shallow coastal estuary formed by the junction of the two large rivers Uruguay and Paraná. It is the second largest freshwater basin in the continent, with a fluvial efflux averaging 24,000 $\mathrm{m}^{3} \mathrm{~s}^{-1}$ (see Framiñan and Brown, 1996; Cabreira et al., 2006). Its water body consists of a two-layer system with freshwater discharge to the ocean in the surface layer, while denser and saltier shelf water ingresses along the ground, leading to a constant saltwater wedge (Acha et al., 2004; Cabreira et al., 2006). Several studies revealed the constraining impact of the Rio de la Plata on species distribution in multiple taxa, most of them featuring a planktonic larval development: e.g. Anthozoa (Zamponi et al., 1998), intertidal molluscs, isopods, and cirripedes (Maytía and Scarabino, 1980), and echinoderms (Bernasconi, 1953; Madsen, 1956). Spivak (1997) and Boschi (2000) report that one-quarter of all decapods from the warm temperate southwestern Atlantic (Cabo Frio, Brazil to Península Valdéz, Argentina) find their southern distributional limit at the northern edge of the Rio de la Plata estuary. Yet, other authors record a continuous distribution of littoral crustaceans throughout these regions (see Lopéz, 1964; Boschi, 1969; Maytía and Scarabino, 1980; Spivak, 1997; Zamponi et al., 1998). For example, there is no interruption in the distribution of the two thoracotreme crabs Neohelice granulata (formerly Chasmagnathus granulatus) (Dana, 1851) and Cyrtograpsus angulatus Dana, 1851. Some faunal differences between southern Brazil-Uruguay and Buenos Aires have been mainly explained by the large estuary Rio de la Plata as determinant of the overall distribution of coastal species (Escofet et al., 1980; Spivak, 1997). However, also the latitudinal changes in the position of the Subtropical-Subantartic Front (BrazilMalvinas confluence) and the freshwater outflow from Patos Lagoon Plume at $32^{\circ} \mathrm{S}$ (see Fig. 1) have both been pointed as possible important ecological barriers north of the Rio de la Plata, in an area comprising the coasts of Santa Catarina and Rio Grande do Sul, Brazil (Palacio, 1982; Spivak, 1997). Whether the freshwater discharge of the Rio de la Plata and its adjacent area is a significant zoogeographical barrier for the distribution of several marine groups, particularly for the cold temperate species, or whether it is a transitional zone with a high degree of mixing of faunal regimes, remains under debate (e.g. Mianzán et al., 2001; Ituarte et al., in 2012).

Among several crustacean taxa inhabiting the shores of the Rio de la Plata, the fiddler crab Uca uruguayensis (Nobili, 1901) (Ocypodidae) is the only Western Atlantic species of the genus found that far south (Crane, 1975; Bogazzi et al., 2001). These crabs have been recorded from Araruama, in Rio de Janeiro in Brazil $\left(22^{\circ} \mathrm{S}\right)$ to northern Argentina $\left(38^{\circ} \mathrm{S}\right)$. They prefer intertidal habitats close to estuaries, with wet sandy or muddy sediment on which to feed (e.g. Rhoads, 1967; Botto and Iribarne, 2000). This rather small species (carapace width $\leq 15 \mathrm{~mm}$ ) is characterized by a fairly wide front and a "lateral, strongly circular" waving display of the males, whose major claw is significantly red. The carapace is of a light green color, whereas courting males are almost white (Crane, 1975: 230).

Since this species seems to be distributed continuously along thousands of kilometers of the southwestern Atlantic coast (Crane, 1975), the consequent question is whether genetic differentiation can be detected between populations north and south of the Rio de la Plata. Due to this wide north-southern distribution, variations in climate and environments are inevitable. While these crabs inhabit mangroves in the tropical regions of Brazil, they occupy estuaries and salt marshes in the temperate realms of Argentina (Spivak 
et al., 1991). Have local populations of this widespread species specialized on the different climates and habitats or can the species be considered as euryoecious? Our study focuses on potential genetic differences between a Brazilian population of Uca uruguayensis and a second one sampled in Argentina with an approximate linear distance of $2,000 \mathrm{~km}$. The Rio de la Plata may work as a barrier to between-population gene flow in impairing larval exchange and thus leading to genetic differentiation of the populations studied.

\section{Material and Methods}

Brazilian samples of Uca uruguayensis were collected from a mangrove in Portinho in Praia Grande, Santos (São Paulo State; 2359.22'S - 46²4.28'W; see Fig. 1), from now on referred to as the Praia Grande population. The corresponding lagoon is associated to the open ocean and salinities in that area vary from 15 to 23 PSU in July,

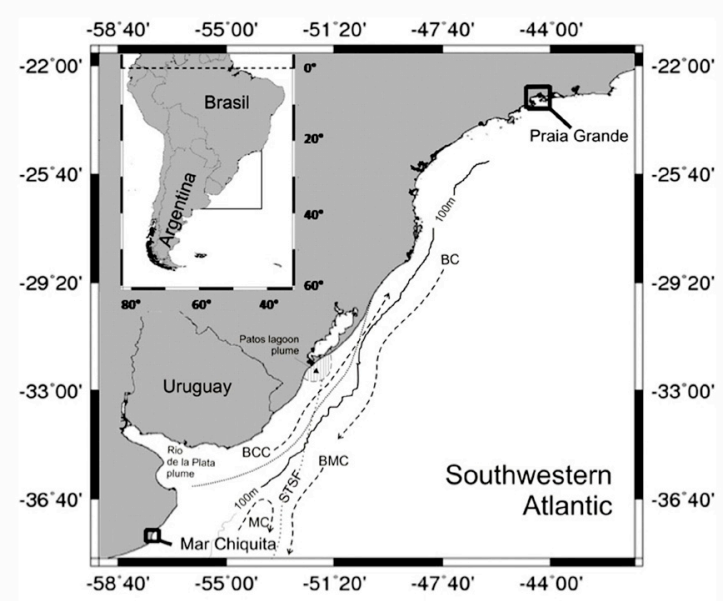

Figure 1. Closeup of oceanographic traits and sampling localities along the western Atlantic coast.

while they are reduced to 9 to 14 PSU in November (T.M. Costa, unpublished data). The specimens from Argentina were sampled in mudflats of Mar Chiquita (37\%44'22.41'S $\left.-57^{\circ} 25^{\prime} 37.92^{\prime} \mathrm{W}\right)$, a coastal lagoon in Buenos Aires State. Mar Chiquita is a flat, brackish lagoon of about $46 \mathrm{~km}^{2}$ near Mar del Plata and is connected to the Western Atlantic. Semidiurnal high tides convey water from the ocean to the lagoon. Physical conditions of the water have great daily variation, with seasonal changes of salinity and temperature (21 to $45 \mathrm{PSU}$; from 17 to $27^{\circ} \mathrm{C}$ in summer and 15 to $2^{\circ} \mathrm{C}$ in winter, Luppi et al., in press). The lagoon is surrounded by sandy beaches and salt marshes of silty deposits, abundantly populated by intertidal crabs: the ocypodid fiddler crab Uca uruguayensis Nobili, 1901, three varunid crabs (Neohelice granulata, Cyrtograpsus angulatus, and $C$. altimanus Rathbun, 1914), and the panopeids Panopeus meridionalis Williams, 1983 and Eurypanopeus depressus (Smith, 1869) (see Spivak et al., 1994).

For the molecular phylogeographic analysis of Uca (Leptuca) uruguayensis, we included ten representatives of each, the Brazilian and the Argentinean population. Mitochondrial DNA was extracted from the muscle tissue of walking legs or chelae using the Puregene buffer system. Being variable enough to detect intraspecific differentiation, but conserved enough to be used for phylogenies of closely related species, the cytochrome c oxidase subunit 1 (Cox1) mitochondrial gene has its justification as the first target genetic marker for intraspecific comparisons like in the current study. A 897 basepair (bp) region of the 3' end of the Cox1 gene was amplified by means of polymerase chain reaction (PCR) $\left(40\right.$ cycles; $45 \mathrm{sec} 94^{\circ} \mathrm{C} / 1$ min $48^{\circ} \mathrm{C} / 75 \mathrm{sec} 72^{\circ} \mathrm{C}$ denaturing/annealing/ elongation temperatures) with the primers COL1b 5'-CCW GCT GGD GGW GGD GAY CC-3' and COH16 5'-CAT YWT TCT GCC ATT TTA GA-3' (see Schubart, 2009). PCR products were purified and sequenced by LGC Genomics GmbH in Berlin, using dideoxy chain termination.

Sequences were read with Chromas Lite 3.01 (Technelysium Pty Ltd., 2005) and corrected manually, where necessary. The sequences were aligned using the alignment 
editor BioEdit 7.0.9.0. Primer regions and non-readable parts in the beginning were cut, resulting in an 823 bp alignment. The absence of stop codons, which might indicate the presence of pseudogenes, was visually checked by using the software Artemis (Rutherford et al., 2000). In order to assess potential restrictions of gene flow among populations, analyses of molecular variance (AMOVA) were carried out with the software Arlequin 3.5.2.1 (Excoffier et al., 2005). Also nucleotide and haplotype diversities were calculated using DnaSP 5.00.07 (Librado and Rozas, 2009) (5,000 permutations) and a haplotype network was constructed using TCS 1.21 (Clement et al., 2000) for population structure investigations.

\section{Results}

The haplotypes of the respective populations (Brazil and Argentina) are not arranged in discernible groups, but rather are distributed homogeneously as can be recognized from the parsimony haplotype network (Fig. 2) obtained with TCS 1.21. They radiate from the central, possibly ancestral haplotype, which is exclusively shared by Brazilian specimens (B-1, 4, 8). Most Brazilian haplotypes can be found in a one-step vicinity to this haplotype except for the haplotypes B-3, B-6, and B-2, which are separated from the central haplotype by two to four mutation steps. Genetic distances are higher within the Argentinean population, with up to eleven mutational steps among them, and none of them being present in more than one sampled specimen. This is reflected in higher haplotype

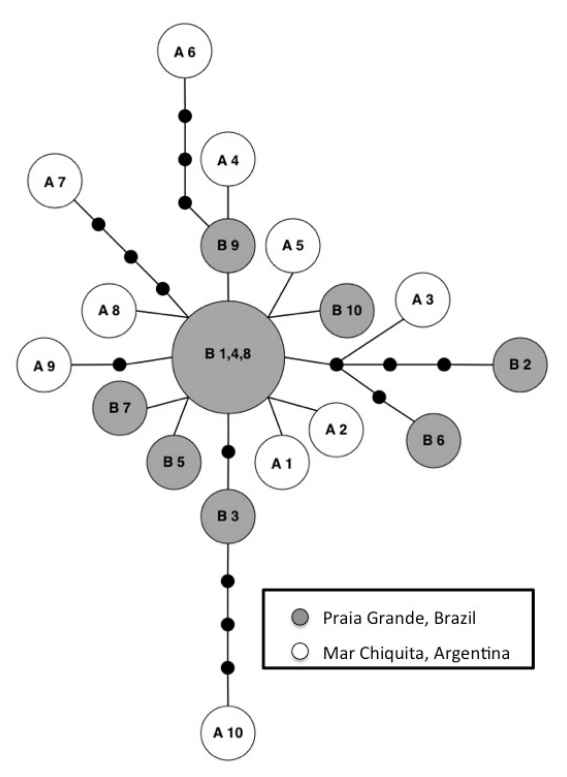

Figure 2. Parsimony network of Uca uruguayensis from southern Brazil (Praia Grande) and northern Argentina (Mar Chiquita) constructed with TCS 1.21 with a connection limit of $95 \%$, derived from Cox $1 \mathrm{mtDNA}$ (823 bp). Numbers identify the individuals within the haplotypes, black spots represent missing haplotypes.

and nucleotide diversities (almost twice as high as the Brazilian value) of the Argentinean population (see Tab. 1), which were calculated using DnaSP Table 2 summarizes the different haplotypes by showing the positions in which they differ from each other.

For estimating gene flow between the two populations, the pairwise difference was estimated by means of Arlequin 3.5.2.1. The obtained $\phi_{\mathrm{ST}}$-value $(-0.014)$ and the corresponding P-value (0.84) suggest no significant restriction of gene flow between the Brazilian and the Argentinean population based on the 20 studied individuals. Sum of squares, variance components and percentage of variance among and within populations are presented in Table 3 .

Table 1. Haplotype and nucleotide diversities of Brazilian and Argentinean populations of Uca uruguayensis as calculated with DnaSP ver. 5.00.07 (5,000 replicates), based on 823 bp of Cox $1 \mathrm{mtDNA}$.

\begin{tabular}{lllll}
\hline & $\mathbf{N}$ (sequences) & $\mathbf{N}$ (haplotypes) & Haplotype diversity $(\mathbf{h d})$ & Nucleotide diversity $\left(\mathbf{P}_{\mathrm{i}}\right)$ \\
\hline Argentina & 10 & 10 & 1.00 & 0.00604 \\
Brazil & 10 & 8 & 0.933 & 0.00314 \\
$\boldsymbol{\Sigma}$ & 20 & 18 & 0.98421 & 0.00456 \\
\hline
\end{tabular}


Table 2. List of cytochrome oxidase subunit $1(823 \mathrm{bp})$ haplotypes, their frequencies and genetic differences found in Uca uruguayensis from Brazil (B) and Argentina (A).

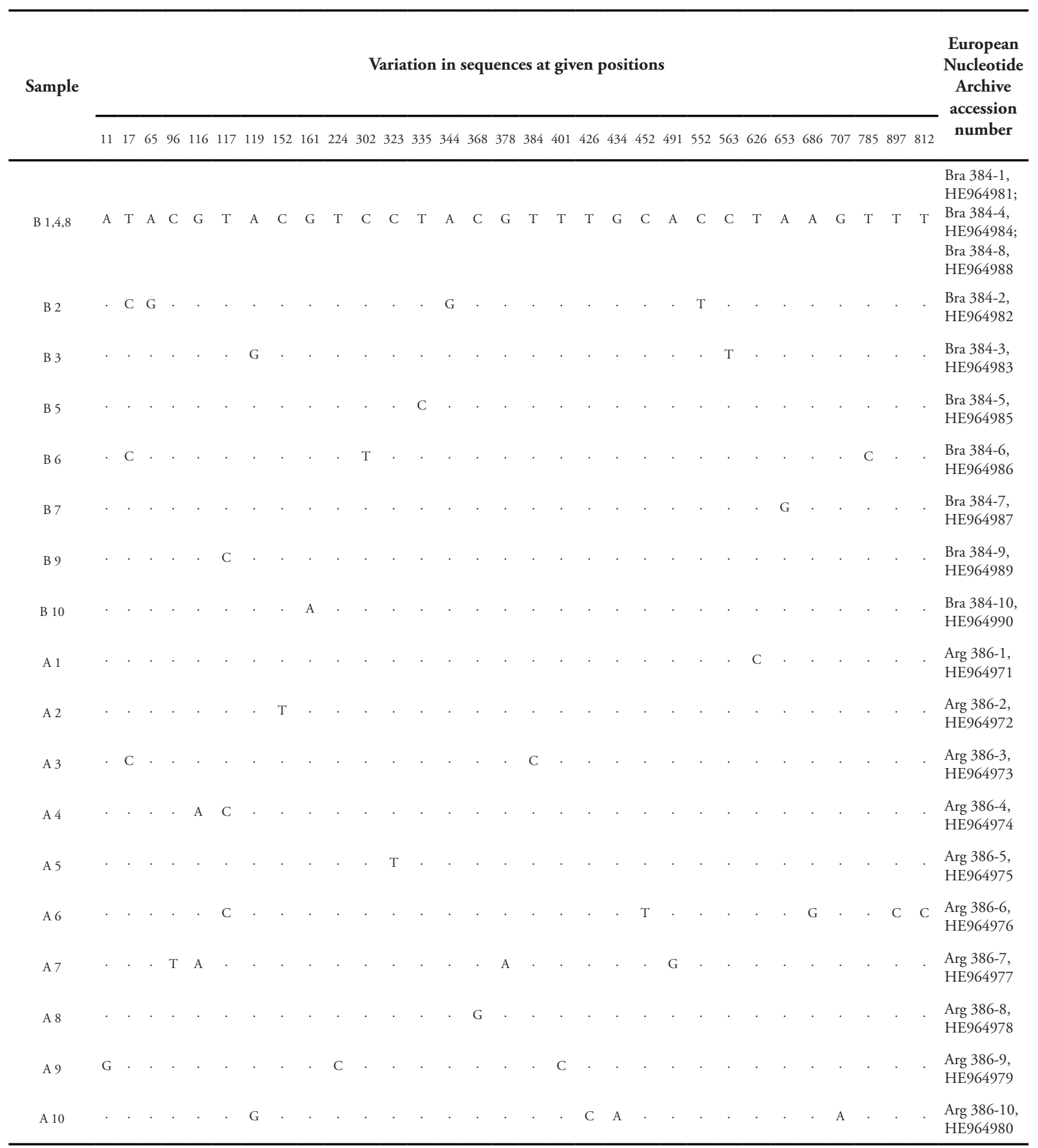

Table 3. Sum of squares, variance components and percentage of variation calculated with Arlequin 3.5.2.1 (5,000 permutations).

\begin{tabular}{lcccc}
\hline Source of variance & d.f. & Sum of squares & Variance components & Percentage of variation \\
\hline Among populations & 1 & 1.600 & $-0.02667 \mathrm{Va}$ & -1.45 \\
Within populations & 18 & 33.600 & $1.86667 \mathrm{Vb}$ & 101.45 \\
Total & 19 & 35.200 & 1.84000 &
\end{tabular}

Fixation Index FST: -0.01449 
Discussion

Many crabs release their larvae during large amplitude nocturnal spring high tides (Morgan, 1987; Morgan and Christy, 1995; Christy and Morgan, 1998), which most likely favors larval emigration from estuaries (Morgan and Anastasia, 2008). Offshore, they undergo a planktonic development of about eight weeks (Hyman, 1920; Williams, 1984; Epifanio, 1988) before they metamorphose to the first crab stage in suitable adult habitats (Brodie et al., 2005). Larvae of estuarine decapod crustaceans can be retained within estuaries, advected to the adjacent continental shelf, or expelled and widely distributed across the shelf (McConaugha, 1988). The larval fate of $U$. uruguayensis is unknown, but for most of the studied species of $U c a$, there is some degree of estuarine retention in addition to a substantial number of zoeae carried to the adjacent continental shelf and then dispersing over hundreds of kilometers along the shoreline (Epifanio et al., 1988). Larvae of Uca travel mostly in discrete patches (Petrone et al., 2005). Being confined to high salinity waters, larvae delay the metamorphosis to crab stage 1 until they approach waters of lower salinity suitable as adult habitats (O'Connor and Epifanio, 1985). Several advantages are associated to this mode of development, including higher potential to reach suitable habitats, extensive gene flow among dispersed populations, and exploitation of different habitats during larval and adult life. Concomitant disadvantages include increased vulnerability to predation in the plankton or starvation and the possibility of advection away from habitats suitable for adult or juvenile existence (Epifanio, 1988). Considering the constraining effect of the Rio de la Plata estuary on other marine invertebrate species, significant larval retention to the parental estuaries may be expected, probably resulting in genetic heterogeneity of the two compared populations.

Based on the mitochondrial Cox1 gene, we found no significant indication for a lack of gene flow between two populations of $U$. uruguayensis located north and south of Rio de la Plata, separated by nearly $2,000 \mathrm{~km}$. Such lack of genetic differentiation over a broad geographic area likely reflects the long-distance dispersal strategy assumed to be common for species of Uca and the lack of strong or permanent barriers to genetic flux within the studied range of $U$. uruguayensis.

Despite the overall lack of genetic structure of the two studied populations according to AMOVA, differences between them remain obvious in terms of haplotype composition (Fig. 1). No studied crab from Mar Chiquita was found to carry the haplotype which is common $(30 \%)$ in the population from Praia Grande and holds a central position in the network. The Argentinean haplotypes are more distant from each other and have longer branches, as reflected in the higher nucleotide diversity (0.006 as opposed to 0.003). The higher genetic variability of the population of Mar Chiquita may suggest at first sight that this population is older than Praia Grande. However, the geographic marginal and fluctuating character of this population at the southern distribution limit suggests that it could be young and vulnerable, and that the apparent high genetic diversity is the result of recruitment pulses from neighboring highly diverse populations (see below). This needs to be tested with more populations and larger sample sizes.

Since both studied populations are located near the northern and southern limits of the latitudinal distribution of $U c a$ uruguayensis, other factors besides the dispersal strategy must be taken into account to explain the genetic structure, including oceanographic regimes that affect the recruitment and larval export in each population.

\section{Northern population (Praia Grande, Brazil)}

The effect of the Rio de la Plata discharge is mainly applied toward the north and east of the outlet, affecting the whole coast of Uruguay and southern Brazil (Burrage et al., 2008). North to this area, there are other geographical barriers that may be acting jointly with the Rio de la Plata, reinforcing its effect as a barrier to larval dispersal. There is a seasonal merging of the plumes of Rio de la Plata and Patos 
Lagoon occurring in winter (Burrage et al., 2008), likely enhancing the effect of the Rio de la Plata to Brazilian coastal waters. North to this area, the coastal waters occupy a narrow strip, with an indistinct eastern margin, a reduced supply of freshwater, a general flow to the south, and a surface temperature ranging from $12^{\circ} \mathrm{C}$ (south and winter) to $27^{\circ} \mathrm{C}$ (north and summer) (Spivak, 1997). These waters flow northward as far north as $25^{\circ} \mathrm{S}$ along the continental shelf, forming what is known as the Brazil Coastal Current. This current runs in opposite direction to the Brazilian Current, which splits off from the shelf, flowing further offshore and southwards (Burrage et al., 2008). So, populations located north to $25^{\circ} \mathrm{S}$, as the studied one from Praia Grande, are likely to have poor larval supply from southern populations, which may be an important constraint to the northward dispersal of this species beyond Cabo Frio, (Rio de Janeiro State) Brazil. This hypothesis agrees with the genetic structure found in the population from São Paulo State, suggesting a relatively recent origin and slightly reduced genetic variability.

\section{Southern population (Mar Chiquita, Argentina)}

The distribution of $U c a$ uruguayensis largely follows the so-called Argentinean Biogeographic Province $\left(23^{\circ}\right.$ to $43-44^{\circ} \mathrm{S}$; see Boschi, 2000), except that the southern boundary of this province extends considerably beyond the southern limit of the species' distribution at $38^{\circ} 34^{\prime} \mathrm{S}$. Such southern limit is puzzling, since there are no obvious environmental discontinuities that might explain it (Bogazzi et al., 2001). There are other exclusively estuarine crab species, such as Neohelice granulata that share the northern limit of its distribution with $U$. uruguayensis, but whose southern limit extends beyond the Argentinean Province, suggesting a lack of biogeographical barriers to the southward dispersal of these crabs, once they cross the Rio de La Plata.

The population dynamics in Mar Chiquita are highly fluctuating (Ribeiro, personal communication). Spivak et al. (1991) report that the density of fiddler crabs in this salt marsh decreased during the 1960's until their virtual disappearance by the beginning of the 1970's, but that in the early 1990's, they subsequently reappeared. Ancillary information on recruitment between 1993 and 1996 also show a very variable recruitment success of the Mar Chiquita population ( $T$. Luppi, personal communication; Valero et al., 1999). Such a recent event of possible recolonization (bottleneck) might have led to a rather homogenous genetic structure within the Mar Chiquita population. But surprisingly, the haplotype network reveals moderate differentiation which is stronger pronounced than the genetic differentiation among the Praia Grande population.

South of the Rio de la Plata, there are only two more populations of $U$. uruguayensis (north and south of Mar Chiquita), thus the distribution of this species into Argentina covers less than 300 kilometers. The southernmost permanent population inhabits Bahía Samborombón (35³0' - 36²2'S), where it is the dominant intertidal species (Boschi, 1964), reaching densities up to 140 crabs $\mathrm{m}^{-2}$ (Iribarne and Martínez, 1999). The two remaining populations are found a few hundred kilometers south, at Mar Chiquita coastal lagoon: $37^{\circ} 46^{\prime} \mathrm{S}$ - 57 $27^{\prime} \mathrm{W}$; Spivak et al., 1991) and at the Quequén Grande (Salado) Estuary (38³4'S; Boschi et al., 1992; Bogazzi et al., 2001). Bogazzi et al. (2001) reported a clear pattern of decreasing density and abundance of $U$. uruguayensis with latitude when comparing these three populations. They did not find any evidence of population differences in reproduction timing, fecundity, eggs and larval sizes, nor in the amount of energy allocated to eggs. Nevertheless, they found differences in large adult size frequency distribution, which they explained by differences in larval supply. Recruitment (as inferred from size frequency distribution) was continuous only at Samborombón (Iribarne and Martínez, 1999), while it was not evident at more southern estuaries.

For species whose larvae are advected from the estuary, as it seems to be the case in $U$. uruguayensis, year-to-year variations in transport processes can alter the year-class 
strength (McConaugha, 1988), which gives an indication on their spawning and survival success. Based on wind patterns, Bogazzi et al. (2001) suggested that supply of larvae is the limiting factor for recruitment of southern Argentinean populations and that wind patterns in the coastal zone (southward and onshore) provide more favorable conditions to settlement at the northern (Samborombón Bay) than at the southern estuaries. Recruitment of estuarine populations depends on two sources for larval supply, those provided by the population itself (self-recruitment or autochthonous recruitment) and those imported from neighboring populations (allochthonous recruitment). It was stated that there is a positive relationship between selfrecruitment and population size (e.g. SaenzAgudelo et al., 2011). Since the size of the Mar Chiquita population, although fluctuating, was always relatively small compared to northern populations, it is expected to have a low rate of self-recruitment. Then, the registered fluctuations on population size at Mar Chiquita must be mainly due to the contribution of larvae from other populations. Indeed, it was speculated that Samborombón Bay may act as the parental stock for Mar Chiquita population (Bogazzi et al., 2001), even if there is no direct evidence of it. Future genetic comparisons should thus include this potential source population and compare a) larger sample sizes and b) temporal differences between years in Mar Chiquita.

In view of the local oceanographic regimes and ecological data available, the most suitable explanation to the haplotype structure found in this study is that, even if the Rio de la Plata acted intermittently as a barrier to a broad larval dispersal (hence constraining gene flow between populations of Argentina and Brazil-Uruguay), the current comparison does not allow recognizing it. The studied Brazilian population from Praia Grande seems to be relatively young or characterized by higher retention and/or self-recruitment. This is not surprising, considering that the population is located at the almost northern limit of the species' distribution. Assuming that the recruitment of larvae in Praia Grande is barely or not influenced by the populations south of the Rio de la Plata (which would be the case considering the oceanographic regimes and Brazilian currents mentioned above), the dominant haplotype that we find in this population must be also the most abundant in the original source population(s) north of Rio de la Plata or reflects a founder effect.

Assuming a sporadical ingression of larvae from populations north of the Rio de la Plata into Argentina, it is probable that the effect of the addition of new haplotypes by new settlers from northern populations is buffered in Samborombón, but becomes more noticeable in small fluctuating populations as Mar Chiquita. Given the larval ecology and oceanographic regime, a more suitable explanation to the haplotype structure of the Mar Chiquita population may lie in the occurrence of episodic events of successful recruitment, sufficiently spaced in time to allow diminution of population size to the point where recolonization by larvae from different source populations (mainly Samborombón, but sporadically from populations north to the mouth of Rio de la Plata) will increase genetic variability. The main difference between the two populations may reside in the fact that one of them (Praia Grande) may show some selfrecruitment and retention, whereas the second (Mar Chiquita) depends on new colonizations from genetically diverse populations to the north.

Overall, it can be said that our small dataset on Uca uruguayensis, from the vicinity of its northern and southern distribution limits, does not reveal any marked intraspecific differentiation or geographic structure. The tested geographic range included the Rio de la Plata and thus fails to indicate a role of this huge estuary as biogeographic boundary, at least in this species. Nevertheless, the haplotype network suggests that the distribution of haplotypes is not absolutely homogeneous and it therefore appears worthwhile to test more individuals and populations at different time intervals, particularly populations from Samborombón Bay and the southern coast of Brazil (Rio Grande do Sul, Santa Catarina) and Uruguay, to understand coastal gene flow 
and larval transport across the mouth of the Rio de la Plata.

\section{Acknowledgments}

We thank Tânia M. Costa and Karine Colpo for their help during collection of the target species from Brazil and Fernando L. M. Mantelatto for his continuous support and being our counterpart in the exchange project funded by the DAAD (project number D/08/11624). Thanks also to Theo Poettinges and Nicolas Thiescelin for technical assistance.

\section{References}

Acha, E.M.; Mianzan, H.W.; Guerrero, R.A.; Favero, M. and Bava, J. 2004. Marine fronts at the continental shelves of austral South America, physical and ecological processes. Journal of Marine Systems, 44(1-2): 83-105.

Avise, J.C. 2004. Molecular Markers, Natural History, and Evolution. Sunderland, Massachusetts, USA: Sinauer Associates Inc.

Bernasconi, I. 1953. Monografía de los equinoideos argentinos. Anales del Museo de Historia Natural, Montevideo, 2(6): 1-58.

Bisbal, G.A. 1995. The southeast South American shelf large marine ecosystem. Marine Policy, 19(1): 21-38.

Bogazzi, E.; Iribarne, O.; Guerrero, R. and Spivak, E. 2001. Wind pattern may explain the southern limit of distribution of a south western Atlantic fiddler crab. Journal of Shellfish Research, 20: 353-360.

Boschi, E.E. 1964. Los crustáceos decápodos brachyura del litoral bonaerense (República Argentina). Boletín del Instituto de Biología Marina, 6: 1-76.

Boschi, E.E. 1969. Estudio biológico pesquero del camarón Artemesia longinaris Bate de Mar del Plata. Boletín del Instituto Biología Marina, 18: 5-39.

Boschi, E.E. 2000. Species of decapod crustaceans and their distribution in the American marine zoogeographic provinces.
Revista de Investigación y Desarrollo Pesquero, 13: 7-136.

Boschi, E.E.; Fischbach, C.E. and Iorio, M.I. 1992. Catálogo ilustrado de los crustáceos estomatópodos y decápodos marinos de Argentina. Frente Maritimo, 10: 7-94.

Botto, F. and Iribarne, O. 2000. Contrasting effects of two burrowing crabs (Chasmagnathus granulata and Uca uruguayensis) on sediment composition and transport in estuarine environments. Estuarine, Coastal and ShelfScience, 51: 141151.

Briggs, J.C. 1974. Marine Zoogeography. New York: McGraw-Hill.

Brodie, R.J.; Behum, M.E.; Monroe, E.; Glenn, N. and Staton, J.L. 2005. Recruitment to adult habitats following marine planktonic development in the fiddler crabs $U c a$ pugilator, U. pugnax, and Uca minax. Marine Biology, 147: 105-111.

Burrage, D.; Wesson, J.; Martinez, C.; Pérez, T.; Möller Jr., O. and Piola, A. 2008. Patos Lagoon outflow within the Rio de la Plata plume using an airborne salinity mapper: Observing an embedded plume. Continental Shelf Research, 28: 1625-1638.

Cabreira, A.G.; Madirolas, A.; Alvarez Colombo, G.; Acha, E.M. and Mianzan, H.W. 2006. Study of the Rio de la Plata estuarine front. ICES Journal of Marine Science, 63: 1718-1725.

Christy, J.H. and Morgan, S.G. 1998. Estuarine immigration by crab postlarvae: mechanisms, reliability and adaptive significance. Marine Ecology Progress Series, 174: 51-65.

Clement, M.; Posada, D. and Crandall, K.A. 2000. TCS: a computer program to estimate gene genealogies. Molecular Ecology, 9: $1657-1660$.

Crane, J. 1975. Fiddler Crabs of the World: Ocypodidae: Genus Uca. Princeton University Press, Princeton, New Jersey, USA.

Epifanio, C.E. 1988. Transport of invertebrate larvae between estuaries and the continental shelf, larval fish and shellfish transport through inlets. American Fisheries Society Symposium, 3: 104-114.

Epifanio, C.E.; Little, K.T. and Rowe, P.M. 
1988. Dispersal and recruitment of fiddler crab larvae in the Delaware River estuary. Marine Ecology Progress Series, 43: 181-188.

Escofet, A.; Gianuca, N.; Maytía, S. and Scarabino, V. 1980. Playas arenosasdel Atlántico Sudoccidental entre los $29^{\circ}$ y $43^{\circ}$ LS: Consideraciones generales y esquema biocenológico. Memorias del Seminario sobre Ecología Bentónica y Sedimentación de la Plataforma Continental del Atlántico Sur. UNESCO, Montevideo, 245-258.

Excoffier, L.; Laval, G. and Schneider, S. 2005. Arlequin ver. 3.0: An integrated software package for population genetics data analysis. Evolutionary Bioinformatics Online, 1: 47-50.

Framiñan, M.B. and Brown, O.B. 1996. Study of the Rio de la Plata turbidity front: Part I. Spatial and temporal distribution. Continental Shelf Research, 16(10): 12591282.

Gilbert, C.R. 1972. Characteristics of the western Atlantic reef-fish fauna. Quarterly Journal of the Florida Academy of Sciences, Gainesville, 35: 130-144.

Greenfield, D. W. 1988. A review of the Lythrypnus mowbrayi complex (Pisces: Gobiidae), with a description of a new species. Copeia, XX: 460-470.

Greenfield, D. W. 1989. Priolepis dawsoni n. sp. (Pisces: Gobiidae), a third Atlantic species of Priolepis. Copeia, XX 397-401.

Hedgecock, D. 1986. Is gene flow from pelagic larval dispersal important in the adaptation and evolution of marine invertebrates? Bulletin of Marine Science, 39: 550-564.

Hyman, O.W. 1920. The development of Gelasimus after hatching. Journal of Morphology, 33: 485-525.

Iribarne, O. and Martínez, M. 1999.Predation on the Southwestern fiddler crab (Uca uruguayensis) by migratory shorebirds (Pluvialis dominica, P. squatarola, Arenaria interpres and Numeniu sphaeopus). Estuaries, 22: 47-54.

Ituarte R.B.; D’Anatro, A.; Luppi, T.A.; Ribeiro, P.D.; Spivak, E.D.; Iribarne, O.O. and Lessa, E.P. 2012. Population Structure of the SW Atlantic estuarine crab Neohelice granulata throughout its range: a genetic and morphometric study. Estuaries and Coasts,
35 (5) 1249-1260.

Lessios, H.; Kane, J. and Robertson, D. 2003. Phylogeography of the pantropical sea urchin Tripneustes: contrasting patterns of population structure between oceans. Evolution, 57: 2026-2036.

Librado, P. and Rozas, J. 2009. DnaSP v5: A software for comprehensive analysis of DNA polymorphism data. Bioinformatics, 25: 1451-1452.

López, R.B. 1964. Problemas en la distribución geográfica de los peces marinos suramericanos. Boletin del Instituto de Biología Marina, 7: 57-63.

Luppi T.M.; Bas, C.; Méndez Casariego, A.; Albano, M.; Lancia J., Kittlein, M.; Rosenthal, A.; Farías, N.; Spivak, E. and Iribarne, O. In press. The influence of habitat, season and tidal regime in the activity of the intertidal crab Neohelice (=Chasmagnathus) granulata. Helgoland Marine Research. DOI: 10.1007/s10152012-0300-9.

Madsen, F. J. 1956. Reports of the Lunds University Chile Expedition 1948-49, 24, Asteroidea, with a survey of the Asteroidea of the Chileans helf. Acta University of Lunds (N.S.), 52: 1-53.

Maytía, S. and Scarabino, V. 1980. Las comunidades del litoral rocoso del Uruguay: zonación, distribución local y consideraciones biogeográficas. Memorias del Seminario sobre Ecología Bentónica y Sedimentación de la Plataforma Continental del Atlántico Sur. UNESCO, Montevideo, 149-156.

McConaugha, J.R, 1988. Export and reinvasion of larvae as regulators of estuarine decapod populations, Larval fish and shellfish transport through Inlets. American Fisheries Society Symposium, Bethesda MD: 104114.

Mianzán, H.; Acha,E.M.; Guerrero,R.A.; Ramírez,F.C.; Sorarrain, D.R.; Simionato, C. and Borus, J., 2001. South Brazilian marine fauna in the Rio de la Plata Estuary: Discussing the barrier hypothesis. IX COLACMAR, San Andrés, Colombia, Septiembre 16-20, extended abstract, 1-4. Morgan, S.G. 1987. Adaptive significance of 
hatching rhythms and dispersal patterns of estuarine crab larvae: avoidance of physiological stress by larval export? Journal of Experimental Marine Biology and Ecology, 113: 71-78.

Morgan, S.G. and Anastasia, J.R. 2008. Behavioral tradeoff in estuarine larvae favors seaward migration over minimizing visibility to predators. Proceedings of the National Academy of Sciencess, 105: 222-227.

Morgan, S.G. and Christy, J.H. 1995. Adaptive significance of the timing of larval release by crabs. American Naturalist, 145: 457- 479.

Nobili, G. 1901. Decapodi raccolti dal Dr. Filippo Silvestri nell'America meridionale. Bollettino dei Musei di Zoologia ed Anatomia comparata della $R$. Università di Torino, 16: $1-16$.

O'Connor, N.J. and Epifanio, C.E. 1985. The effect of salinity on the dispersal and recruitment of fiddler crab larvae. Journal of Crustacean Biology, 5: 137-145.

Palacio, F.J. 1982. Revisión zoogeográfica marina del sur del Brasil. Boletim do Instituto Oceanográfico, 31(1): 69-92.

Palumbi, S.R. 1994. Genetic divergence, reproductive isolation, and marine speciation. Annual Review of Ecology and Systematics, 25: 547-572.

Palumbi, S.R. 1996. Macrospatial genetic structure and speciation in marine taxa with high dispersal abilities. In: Ferraris, J.D., Palumbi, S.R., ed. Molecular Zoology: Advances, Strategies, and Protocols. New York: Wiley-Liss, 101-113.

Petrone, C.; Jancaitis, L.B.; Jones, M.B.; Natunewicz, C.C.; Tilburg, C.E. and Epifanio, C.E. 2005. Dynamics of larval patches: spatial distribution of fiddler crab larvae in Delaware Bay and adjacent waters. Marine Ecology Progress Series, 293: 177-190.

Rhoads, D. 1967. Biogenic reworking of intertidal and subtidal sediments in Barnstable Harbor and Buzzard Bay, Massachusetts. Journal of Geology, 75: 461474.

Rutherford, K.; Parkhill, J.; Crook, J.; Horsnell, T.; Rice, P.; Rajandream, M.A. and Barrell, B. 2000. Bioinformatics, 16(10): 944-5.

Saenz-Agudelo, P.; Jones, G.P.; Thorrold,
S.R. and Planes, S. 2011. Connectivity dominates larval replenishment in a coastal reef fish metapopulation. Proceedings of the Royal Society B, 278: 2954-2961

Schubart, C.D. 2009. Mitochondrial DNA and decapod phylogenies: the importance of pseudogenes and primer optimization. p. 47-65. In: J.W. Martin, K.A. Crandall and D.L. Felder (eds), Decapod Crustacean Phylogenetics. Crustacean Issues, Vol. 18. London, CRC Press

Spivak, E. 1997. Los crustáceos decápodos del Atlántico sudoccidental $\left(25^{\circ}-55^{\circ}\right.$ S): distribución y ciclos de vida. Investigaciones Marinas, 25: 69-91.

Spivak, E.D.; Gavio, M.A. and Navarro, C.E. 1991. Life History and Structure of the World's Southernmost Uca Population: $U c a$ uruguayensis (Crustacea, Brachyura) in Mar Chiquita Lagoon (Argentina). Bulletin of Marine Science, 48: 679-688.

Spivak, E.; Anger, K.; Luppi, T.; Bas, C. and Ismael, D. 1994. Distribution and habitat preferences of two grapsid crab species in Mar Chiquita Lagoon (Province of Buenos Aires, Argentina). Helgoländer Meeresunter Sucheenger, 48: 59-78.

Valero, J.; Luppi, T. and Iribarne, O. 1999. Size indicator of swimming speed in crab megalopae. Journal of Shellfish Research, 18: 663-666.

Williams, A.B. 1984. Shrimps, lobsters, and crabs of the Atlantic coast of the eastern United States, Maine to Florida. Washington, DC: Smithsonian Institution Press.

Zamponi, M.O.; Belém, M.J.C.; Schlenz, E. and Acuña, F.H. 1998. Distribution and some ecological aspects of Corallimirpharia and Actiniaria from shallow waters of the South American Atlantic coasts. Physis A, 55: 31-45.
Submitted 20 December 2011 Accepted 10 June 2012 